\title{
Growth Performance of Japanese Quail (Coturnix coturnix japonica) Reared on Deep Litter and Cages in the Hot Humid Tropics of Southern Bénin Republic
}

\author{
Serge Alindekon, Okhiomah Ahmed Abu, Olaniyi Jacob Babayemi, Paul Agblo and \\ Mehouede Yvonne Adjovi-Boco
}

\begin{abstract}
Animal Science Faculty, University of Ibadan, Ibadan, Nigeria
Corresponding author email: alindekonserge@gmail.com
\end{abstract}

\begin{abstract}
The performance of male and female quails reared separately in cages and on deep litter was investigated. One hundred and eighty 3-week old quails managed for five weeks in a $2 \times 2$ factorial arranged in a randomized complete block design involving two housing systems, sex and three replicates. Data on weekly body weight, weight change, daily feed and water intakes, feed conversion ratio, carcass yield and costs of production were recorded. It was observed that the amount of daily water consumed by quails between the housing systems $(62.76 \pm 11.21 \mathrm{~mL} / \mathrm{d}$ on deep litter vs. $66.96 \pm 12.18 \mathrm{~mL} / \mathrm{d}$ in cage system, $\mathrm{p}>0.05)$ were the same. However, quails housed on deep litter consumed more feed from 43-56 days of age $(25.34 \pm 1.77 \mathrm{~g} / \mathrm{d}$ vs. $22.99 \pm 1.55 \mathrm{~g} / \mathrm{d})$ and grew faster during the first week of that period $(3.33 \pm 1.70 \mathrm{~g} / \mathrm{d}$ vs. $0.69 \pm 0.87 \mathrm{~g} / \mathrm{d}$ ). Gain in body weight was noticed from day 22 to day 49 but a sudden decline thereafter for all quails regardless of sex and housing system. Carcass yield was not affected by housing system but values for thighs, empty gizzard and liver of quails kept on deep litter were higher (respectively $12.95 \pm 0.86 \%$ vs. $11.99 \pm 0.83 \%, 2.12 \pm 0.18 \%$ vs. $1.84 \pm 0.20 \%, 2.11 \pm 0.59 \%$ vs. $1.88 \pm 0.43 \% ; p<0.05)$. Production costs were the same $(p>0.05)$ whether on deep litter $(3414.30 \pm 172.95 \mathrm{CFA} / \mathrm{kg})$ or in cages $(3283.43 \pm 77.72 \mathrm{CFA} / \mathrm{kg})$. Nevertheless, the production cost per kilogram of carcass of male quails was lower compared to females (3205.88 $\pm 138.95 \mathrm{CFA} / \mathrm{kg}$ vs. $3484.35 \pm 131.57 \mathrm{CFA} / \mathrm{kg}$, respectively) regardless of the housing system. Sex and age of quails affect performance and not the type of housing system.
\end{abstract}

Keywords: Japanese quail, housing systems, sex, performance, humid tropics

Abstrak. Penelitian ini bertujuan untuk mempelajari performan puyuh jantan dan betina yang dipelihara secara terpisah menggunakan bahan litter tebal. Sebanyak 180 ekor puyuh berusia 3 minggu dipelihara selama lima minggu menggunakan pola faktorial rancangan acak kelompok $2 \times 2$ dengan dua sistem kadang, jenis kelamin dan tiga ulangan. Data yang diamati meliputi bobot badan mingguan, perubahan bobot, dan konsumsi pakan dan minum harian. Data menunjukkan bahwa jumlah konsumsi air minum harian antara kedua sistem kandang tidak ada perbedaan $(62.76 \pm 11.21 \mathrm{~mL} / \mathrm{d}$ pada kandang litter vs. $66.96 \pm 12.18 \mathrm{~mL} / \mathrm{d}$ in sistem cage, $p>0.05$ ). Puyuh yang dikandangkan menggunakan litter mengkonsumsi lebih banyak pakan dari umur ke $43-56$ hari $(25.34 \pm 1.77 \mathrm{~g} / \mathrm{hr}$ vs. $22.99 \pm 1.55 \mathrm{~g} / \mathrm{hr})$ dan tumbuh lebih cepat selama minggu pertama periode tersebut $(3.33 \pm 1.70 \mathrm{~g} / \mathrm{hr} v$ s. $0.69 \pm 0.87 \mathrm{~g} / \mathrm{hr})$. Penambahan bobot badan tampak terlihat pada hari ke 22 sampai 49 namun terjadi penurunan bobot tiba-tiba setelah umur tersebut. Jumlah karkas tidak dipengaruhi oleh sistem perkandangan namun paha, gizzard dan hati dari puyuh yang dipelihara menggunakan litter diperoleh hasil yang lebih banyak (berurutan $12.95 \pm 0.86 \%$ vs. $11.99 \pm 0.83 \%, 2.12 \pm 0.18 \%$ vs. $1.84 \pm 0.20 \%, 2.11 \pm 0.59 \%$ vs. $1.88 \pm 0.43 \% ; p<0.05)$. Biaya produksi sama $(p>0.05)$ baik dengan litter $(3414.30 \pm 172.95 \mathrm{CFA} / \mathrm{kg})$ atau menggunakan cages $(3283.43 \pm 77.72 \mathrm{CFA} / \mathrm{kg})$. Biaya produksi per kilogram karkas jantan lebih rendah dibanding betina (3205.88 $138.95 \mathrm{CFA} / \mathrm{kg}$ vs. $3484.35 \pm 131.57 \mathrm{CFA} / \mathrm{kg}$, berurutan) terlepas dari jenis kandang. Jenis kelamin dan umur puyuh mempengaruhi performans, sedangkan tipe kandang tidak berpengaruh.

Keywords: Puyuh jepang, sistem perkandangan, jenis kelamin, performans, tropis lembab

\section{Introduction}

The Japanese quail is a cheaper and novel source of animal protein suitable for diversifying animal agriculture (Kaur and Mandal, 2015). Quail farming also possesses prospects in intensive commercial poultry production for its unique characteristics of fast growth, early sexual maturity, high rate of egg production, short generation interval and shorter incubation period (Nasar et al., 2016). Hence, devel- 
oping quail meat industry in middle and lowincome economies may significantly contribute to the food security and will be of economic interest. However, there have been implications for housing type and management conditions in order to achieve set livestock production objectives. In fact, changes in the rearing systems which, reduce stress conditions by allowing for comfort and bird welfare increase significantly zootechnical performance (Dawkins et al., 2004). In addition, consumers have shown great interest in production systems, animal welfare, quality of life, etc. and these have resulted in changes that guarantee their choices of new products (Main et al., 2014). But, unlike for chickens, the effect of housing has been poorly studied for the quail. Therefore, the present study was carried out to evaluate the effect of housing system (cages and deep litter) on production performance of Japanese quail and to suggest the ideal system of housing in the hot and humid region in Republic of Bénin.

\section{Materials and Methods}

\section{Site and period of study}

The experiment was carried out at Centre de Formation Professionnelle et de Promotion de L'Aviculture-Cuniculture Tropicale (CFPPA$\mathrm{CT}$ ), southern of Bénin Republic and lasted 5 weeks from February-May, 2017. The study area has a sub-equatorial climate characterized by two rainy seasons (April to July and October to November) and two dry seasons (August to September and December to March) while the average rainfall is close to $1200 \mathrm{~mm}$ per year. The average temperature varied between 28.22 and $34.03^{\circ} \mathrm{C}$ and the relative air humidity fluctuated between 60.01 and $76.45 \%$ during the day in the animal house.

\section{Quails and experimental design}

A dual-purpose line of Japanese quail (Coturnix coturnix japonica) was used in the experiment. The quails were housed in a standard tropical open-sided poultry building and were maintained at ambient temperature. The building was of a half-monitor shed type and had a short concrete wall about $0.5 \mathrm{~m}$ height on the top of which chicken mesh is run to the roof. The height of the sides from the foundation to the roof line was $1.5 \mathrm{~m}$ and $2 \mathrm{~m}$ at the centre. Quails had free access to water and were fed ad libitum commercial diet (22\% crude protein and $2939.53 \mathrm{kcal} / \mathrm{kgDM} \mathrm{ME}$ ) from day 22 up to day 56. Light was provided during the night to encourage feed intake throughout the experiment. A total of 1803 week old sexed quails, randomly picked from available stock were used. The experiment consisted of a $2 \times 2$ factorial arrangement in a randomized complete block design involving two treatments (cage and deep litter), the sex as block and three replicates per treatment. Ninety of the selected quails were equally divided in two groups and allocated, according to sex, in six pens with a stocking density of $180 \mathrm{~cm}^{2} /$ bird, each pen was provided with wood shavings as bedding for deep litter (floor group). The remaining birds were placed in six cages at a stocking density of $120 \mathrm{~cm}^{2} / \mathrm{bird}$, according to sex (cage group) i.e. 45 birds of each sex, divided into 3 replicates of 15 birds.

\section{Data Collection}

\section{Zootechnical parameters data}

From 3-8 weeks of age, feed and water leftover, as well as mortality, were recorded on a daily basis while body weight changes were measured on a weekly basis using a sensitive balance. From these data, the feed and water intakes, as well as the feed conversion ratio, were calculated.

\section{Carcass characteristics}

After the final weighing, the quails were fasted for 12 hours but given only water before slaughtering. From each experimental unit, 5 quails were selected. All the selected 
quails were weighed individually, slaughtered by cervical dislocation and bled. The slaughtered quails were weighed again and then scalded in the water of about $70^{\circ} \mathrm{C}$ for $1-2$ minutes before manual removal of feathers. Carcasses consisted of a whole processed quail with neck, and without feet, head, abdominal fat and giblets were packed in plastic bags and chilled at $4^{\circ} \mathrm{C}$ for 24 hours. After this period, the experimental unit average weight of carcasses, cut parts, visceral organs (empty gizzard, heart and liver) and abdominal fat were computed. The carcass yield was calculated as the ratio between the cold carcass and body weight after fasting while the yield of parts and visceral organs were calculated relative to the weight of the cold carcass.

\section{Cost of rearing}

The cost implications of the rearing systems were calculated using inputs in the economic analysis. These involve the cost of labour according to the system, the cost of buildings and pen/cage including facilities, feeding costs and take-off quails' cost. The local price of products, labour and others were quoted in the area as at the time of the experiment.

\section{Data analysis}

The obtained data were subjected to a two-way ANOVA and compared at 5\% significant level using IBM SPSS 21.0 software according to the following model: $Y_{i j k}=\mu+A_{i}+$ $B_{j}+(A B)_{i j}+e_{i j k}$; where $A=$ effects of housing system and $B=$ effects of sex $A B=$ Interaction between housing system and sex. Also $i=1,2$ (1 = deep litter floor, 2 = cages), $\mathrm{j}=1,2$ ( 1 = male, 2 =female), $k=1,2,3$ (for replications). The observed values were the averages of the sequenced experimental units. Means suggesting significant influence of the factors sex, housing system and/or their interaction were separated according to the procedures indicated by Wei et al. (2012).

\section{Results and Discussion}

The growth performance and carcass characteristics of quails according to the housing system and the sex for the overall period of the study are presented in table 1 . At day 56 (end of the study) the male quails raised in the cage system had the lowest final body weight $(237.89 \pm 9.21 \mathrm{~g})$ while female quails maintained on deep litter had the highest body weight $(257.02 \pm 5.70 \mathrm{~g})$. The body weight gain ranged from 3.72 to $4.02 \mathrm{~g} / \mathrm{d}$ for the overall period of the experiment. Male quails in cage system had the lowest amount of feed daily consumed $(21.71 \pm 3.49 \mathrm{~g} / \mathrm{d})$ while the female quails on deep litter had the highest value $(24.62 \pm 3.26 \mathrm{~g} / \mathrm{d})$. However, a significant effect $(p<0.05)$ of the sex was found for the overall period as female quails ate more than the males $(23.89 \pm 3.86 \mathrm{~g}$ vs. $22.06 \pm 3.45 \mathrm{~g}$, respectively). It was also observed that for the overall period, water intake of quails ranging from $56.23 \pm 8.06 \mathrm{~mL} / \mathrm{d}$ (males on deep litter) to $66.96 \pm 12.18 \mathrm{~mL} / \mathrm{d}$ (females in cage system) was also significantly $(p<0.05)$ influenced by the sex of the quails. In fact, the analysis suggested that female quails drank more than males $(65.91 \pm 12.61 \mathrm{~mL}$ vs. $57.39 \pm 8.29 \mathrm{~mL}$, respectively) irrespective of the housing system.

\section{Body weight of female and male quails ac- cording to housing system}

When the comparison was made irrespective of the housing systems, significant $(p<0.01)$ effect of the sex was recorded at the age of 28, 42 and 49 days. In fact, female quails were significantly $(p<0.01)$ heavier than the male quails at these ages with respective values being $\quad 163.34 \pm 5.62 \mathrm{~g} \quad v s .151 .86 \pm 6.12 \mathrm{~g}$; $252.94 \pm 12.40 \mathrm{~g} \quad$ vs. $228.53 \pm 13.78 \mathrm{~g}$; $262.96 \pm 8.51 \mathrm{~g}$ vs. 246.69 $\pm 7.21 \mathrm{~g}$. However, there was no significant effect of either the housing system or its interaction with the sex on the body weight throughout the rearing period. 
Table 1: Growth performance and carcass characteristics of female and male quails according to housing system for the overall period

\begin{tabular}{|c|c|c|c|c|c|c|c|}
\hline & \multicolumn{2}{|c|}{ Cage system } & \multicolumn{2}{|c|}{ Deep litter } & \multicolumn{3}{|c|}{ Significance } \\
\hline & Female & Male & Female & Male & HS & $\mathbf{S}$ & HS X S \\
\hline \multicolumn{8}{|l|}{ Growth performance } \\
\hline Final body weight (g) & $248.27 \pm 16.82$ & $237.89 \pm 9.21$ & $257.02 \pm 5.70$ & $244.74 \pm 9.11$ & NS & NS & NS \\
\hline $\begin{array}{l}\text { Body weight change } \\
\text { (g/d) }\end{array}$ & $3.85 \pm 0.53$ & $3.72 \pm 0.19$ & $4.02 \pm 0.13$ & $3.79 \pm 0.31$ & NS & NS & NS \\
\hline Daily feed intake (g) & $23.17 \pm 4.38^{\mathrm{a}}$ & $21.71 \pm 3.49^{b}$ & $24.62 \pm 3.26^{\mathrm{a}}$ & $22.42 \pm 3.49^{b}$ & NS & $* *$ & NS \\
\hline Daily water intake (mL) & $66.96 \pm 12.18^{a}$ & $58.55 \pm 8.62^{b}$ & $64.86 \pm 13.37^{a}$ & $56.23 \pm 8.06^{b}$ & NS & $* *$ & NS \\
\hline Feed conversion ratio & $6.09 \pm 0.75$ & $5.84 \pm 0.20$ & $6.13 \pm 0.10$ & $5.93 \pm 0.23$ & NS & NS & NS \\
\hline \multicolumn{8}{|l|}{$\begin{array}{l}\text { Carcass characteristics } \\
\text { (\%) }\end{array}$} \\
\hline Carcass yield & $73.22 \pm 1.83^{b}$ & $78.83 \pm 0.16^{a}$ & $73.79 \pm 1.30^{b}$ & $80.19 \pm 0.85^{a}$ & NS & $* * *$ & NS \\
\hline Breast & $25.24 \pm 2.02^{\mathrm{a}}$ & $23.38 \pm 1.10^{\mathrm{b}}$ & $26.37 \pm 0.68^{a}$ & $22.88 \pm 1.12^{\mathrm{b}}$ & NS & $* * *$ & NS \\
\hline Thighs & $11.39 \pm 0.76^{c}$ & $12.59 \pm 0.22^{\mathrm{b}}$ & $12.47 \pm 0.86^{b}$ & $13.43 \pm 0.66^{a}$ & $* *$ & $* *$ & NS \\
\hline Drumsticks & $9.11 \pm 0.50$ & $9.13 \pm 0.13$ & $9.11 \pm 0.24$ & $9.14 \pm 0.55$ & NS & NS & NS \\
\hline Wings & $10.58 \pm 0.72$ & $10.31 \pm 0.73$ & $10.48 \pm 0.09$ & $10.87 \pm 1.01$ & NS & NS & NS \\
\hline Head & $4.84 \pm 0.04$ & $5.23 \pm 0.11$ & $4.90 \pm 0.44$ & $4.94 \pm 0.13$ & NS & NS & NS \\
\hline Feet & $0.68 \pm 0.12$ & $0.93 \pm 0.05$ & $0.92 \pm 0.08$ & $0.77 \pm 0.23$ & NS & NS & $* *$ \\
\hline Abdominal fat & $1.02 \pm 0.30$ & $1.18 \pm 0.42$ & $0.65 \pm 0.66$ & $0.46 \pm 0.80$ & NS & NS & NS \\
\hline Empty gizzard & $1.84 \pm 0.30^{\mathrm{a}}$ & $1.84 \pm 0.11^{\mathrm{a}}$ & $2.19 \pm 0.21^{b}$ & $2.05 \pm 0.14^{b}$ & $* *$ & NS & NS \\
\hline Heart & $0.68 \pm 0.12$ & $0.93 \pm 0.05$ & $0.92 \pm 0.08$ & $0.77 \pm 0.23$ & NS & NS & $* *$ \\
\hline Liver & $2.27 \pm 0.15^{b}$ & $1.50 \pm 0.07^{d}$ & $2.64 \pm 0.11^{\mathrm{a}}$ & $1.58 \pm 0.11^{\mathrm{c}}$ & $* * *$ & $* * *$ & NS \\
\hline
\end{tabular}

HS: Housing system; S: Sex; NS: Not significant; ${ }^{* *}: \mathrm{p}<0.05 ;{ }^{* *}: \mathrm{p}<0.01$; Means on the same row with different superscripts are significantly $(\mathrm{P}<0.05)$ different

\section{Body weight change of female and male quails according to housing system}

From day 36 to day 42 , the sex of birds had a significant $(p<0.05)$ effect on the body weight change with female quails growing faster than males $(5.63 \pm 1.47 \mathrm{~g} / \mathrm{d} \quad v s$. $3.55 \pm 1.54 \mathrm{~g} / \mathrm{d}$ ). The average body weight change was significantly $(p<0.01)$ affected by the housing system in the period 43-49 days and during that period of age, birds on deep litter grew faster than those in cage system $(3.33 \pm 1.70 \mathrm{~g} / \mathrm{d}$ vs. $0.69 \pm 0.87 \mathrm{~g} / \mathrm{d})$. The loss of weight for all the quails involved in this experiment observed after 49 days was not significantly affected either by sex or the housing system.

\section{Feed and water intake of female and male quails according to housing system}

There was a decline in feed intake after day 49 for all the birds involved in the experiment. Significant $(p<0.05)$ effect of the housing system was recorded during days 43-49 as well as during days 50-56. For these two periods, it appeared that quails housed on deep litter ate more than quails reared in cage. The amounts of feed consumed on a daily basis were $25.34 \pm 1.77 \mathrm{~g}$ vs. $22.99 \pm 1.55 \mathrm{~g}$ and $22.02 \pm 2.46 \mathrm{~g}$ vs. $17.38 \pm 2.37 \mathrm{~g}$, respectively. A significant effect of the sex was found specifically during the periods $36-42$ days $(p<0.01)$ and $50-56$ days $(p<0.05)$, with female quails eating more than the males $(28.63 \pm 1.42 \mathrm{~g}$ vs. $26.44 \pm 0.62 \mathrm{~g}$; $21.15 \pm 3.92 \mathrm{~g}$ vs. $18.24 \pm 2.04 \mathrm{~g}$, respectively). During each one of the recorded periods, there was no significant difference in the 
amount of water consumed daily by quails when comparisons were made across the housing systems. However, the results suggested that the daily water intake was affected significantly $(p<0.01)$ by the sex of the birds specifically at days $36-42$, days $43-49$ and days 50-56 with females always drinking more than males $(78.47 \pm 10.12 \mathrm{~mL}$ vs. $75.62 \pm 9.42 \mathrm{~mL}$; $67.89 \pm 7.42 \mathrm{~mL}$ vs. $53.12 \pm 4.76 \mathrm{~mL}$, respectively).

Feed conversion ratio of female and male quails according to housing system

It was observed that for the overall period day 22 to 56, the feed conversion ratio ranged from $5.84 \pm 0.20$ (males in cage system) to $6.13 \pm 0.10$ (females on deep litter) and nevertheless, across sexes and between the two systems in that period, differences were not evident when data were analysed for feed conversion ratio.

Carcass characteristics, visceral organs relative to cold carcass weight (in \%) of quail birds raised on deep litter and cage systems

At 8 weeks of age, male quails raised on deep litter had the highest value for carcass yield while females kept in cage system had the lowest values $(73.22 \pm 1.83 \%$ vs. $79.51 \pm 0.93 \%$, respectively). However, only the sex of birds had a significant effect in that parameter, with males showing higher carcass yields $(p<0.01)$ than females with respective values being $79.51 \pm 0.93 \%$ vs. $73.51 \pm 1.46 \%$. The comparison of the carcass cut-parts and edible visceral organs relative to carcass weight between the two housing systems according to the sex indicated that the highest percentage of breast muscles relative to carcass weight was observed in female quails raised on deep litter $(26.37 \pm 0.68 \%)$ while the lowest value is presented by male quails also kept on deep litter $(22.88 \pm 1.12 \%)$. There was a formally significant $(p<0.01)$ effect of sex indicating that female birds' breast muscle percentages across the two systems were signifi- cantly higher as compared to males: $25.81 \pm 1.48 \%$ vs. $23.13 \pm 1.03 \%$, respectively. The highest percentage of empty gizzard relative to carcass weight was observed with female quails raised on deep litter $2.19 \pm 0.21 \%$ while the lowest value is presented by male quails kept in cage system $(1.84 \pm 0.11 \%)$. The housing system had a significant effect in quail empty gizzard percentage with floor birds presenting higher empty gizzard percentage as compared to quails housed in cage system ( $2.12 \pm 0.18 \%$ vs. $1.84 \pm 0.20 \%$, respectively). The percentage of thighs ranging from $11.39 \pm 0.76 \%$ to $13.43 \pm 0.66 \%$ was affected significantly $(p<0.05)$ by the type of housing as well as the sex of the bird. However, there was no interaction between these two studied factors. Male quails' thighs were heavier from those of female quails $(13.01 \pm 0.64$ vs. $11.93 \pm 0.94)$ and when the comparison was made across the housing systems, it appeared that quails kept on deep litter had heavier thighs than those raised in cage system $(12.95 \pm 0.86 \%$ vs. $11.99 \pm 0.83 \%)$. Conversely, no significant difference in drumsticks, wings, head and abdominal fat respective percentages relative to carcass weight was found when the effects of sex, the housing system, as well as their interactions were investigated. However, when feet and heart percentages were subjected to analysis, it was found that there is no overall effect of either the housing system or sex of the birds, but surprisingly there was a crossover interaction $(p<0.05)$. Again, it was observed that the percentage of liver ranging from $1.50 \pm 0.07 \%$ to $2.64 \pm 0.11 \%$ was affected $(p<0.05)$ by both the housing system and the sex. Female quails had higher relative liver weights as compared to male quails $(2.45 \pm 0.23 \%$ vs. $1.54 \pm 0.09 \%)$ and when the comparison was made across the housing systems, birds kept on deep litter had heavier liver than those raised in cage system (2.11 $\pm 0.59 \%$ vs. $1.88 \pm 0.43 \%)$. 
Cost of production in CFA per kg of the carcass of female and male quails according to the housing system

It was observed that at 56 days old, the cost of production in CFA per $\mathrm{kg}$ of carcass of male quails raised in cage system had the lowest value $(3128.33 \pm 155.53 \mathrm{CFA} / \mathrm{kg})$ and females kept on deep litter had the highest cost of production (3545.17 \pm 131.77 CFA $/ \mathrm{kg}$ ). However, the results suggest that only the sex of quails had a significant effect on the cost of production in CFA per kg of carcass, with the production cost of 1kilogram of male quails' carcass relatively lower as compared to females $\quad(3205.88 \pm 138.95 \mathrm{CFA} / \mathrm{kg} \quad v s$. $3484.35 \pm 131.57$ CFA $/ \mathrm{kg}$, respectively).

\section{Results and Discussion}

\section{Effect of housing system on quail perfor- mance}

In general, all the birds used in the present study in both systems of housing showed good performance without any mortality, clinical sign of diseases. Birds raised on deep litter had access to a suitable substrate for dust bathing, scratching; enough space for stretching and wings flapping etc. known as the comfort behaviours in bird (Favreau-Peigné et al., 2014). This might explain why birds on deep litter consumed more and grew faster than those in cage system in the period 43-49 days because deep litter allows the birds to experience the best possible conditions in which to live and develop. However, according to Fouad et al. (2008), the difference in productive performance could be attributed to feed wastage in cage birds compared to birds raised on deep litter. Although a significant effect of housing system on feed intake with quails on deep litter consuming more than cage group was recorded in the period 50-56 days, no difference was observed in body weight change. Tavaniello (2014) suggests that the main reason behind this is that as is typical of all ani- mals, quails experience a period a rapid growth early in their development. This is then followed by a slow rate of growth as more feed was used in maintaining the already existing body structure. As a result, body weight change was much better in the first weeks of the quails' production and then declines. An attractive hypothesis to consider is that overdrinking or polydipsia, which is an abnormal drinking behaviour possibly as a result of a consequence of environmental stress (Shields and Greger, 2013) were expected to account also for the use of cages in quail but, the results suggested that the housing system did not affect the water consumption. The results suggested that the weights of empty gizzard of birds kept on deep litter were higher. These results may be attributed to a highly functional gizzard due to frequent intake of litter materials high in fibre and might have resulted in the greater development of this organ (De Verdal et al., 2010; Zhao et al., 2012). The same observations for relative weights of thighs may be ascribed to the fact that quails kept on deep litter expressed high levels of scratching behaviour that might have resulted in the greater development of their thighs. This finding is in agreement with $\mathrm{Li}$ et al. (2017) who suggested that an increased proportion of leg muscles could be connected to an increased motor activity in chickens. Finally, the economic analysis revealed that the cost of production in CFA per kg of the carcass of quail was not significantly affected by the housing system. Interestingly, however, the evidence in the literature is contradictorily suggesting that the effect of housing system on production profitability in avian meat is well known and was reported as significant (Fouad et al., 2008; Shields and Greger, 2013). Such result is possibly related to the housing systems and/or to the strain of quail used in the current study. 


\section{Effect of sex on quail performance}

At 28,42 and 49 days the body weights of quails were affected by the sex with female quails heavier than males. This effect of sex accounted also for both body weight change (specifically from 36 to day 42 ) and feed intake, for the overall period. Such differences were rather expected and could be ascribed to the fact that unlike practically all other domestic avian species, sexual dimorphism in quail favours the female (Bonos et al., 2010; Khaldari et al., 2010). In addition, a significant difference for thigh and breast meat percentages was found between sexes with females showing higher figures than male quails. Nevertheless, the study suggested that the dressing percentage was higher in male than female. Such differences, also noticed by Tavaniello et al. (2014) may be related to the growth and muscle development potential between males and females (Sogunle et al., 2008) and/or to the large reproductive organs in female quails, such as ovary and oviducts (Marks, 1993). Except for the liver percentage, the study disagrees with the report of Alamuoye and Ojo (2015) which suggested that there was a significant difference between sexes in respect to other visceral organs in quail. Finally, the results suggested that male quails are more profitable than females; and this might probably due to the fact that in quail, though the sexual dimorphism favours the females in terms of body weight, males are characterized by higher carcass yield ( $\mathrm{Ta}$ vaniello, 2014).

\section{Conclusions}

The welfare status of the quails was not compromised either under cage conditions or on deep litter. The housing system is not, therefore, the most important factor affecting performance in quail broiler. However, male quails fetched more profit than female regardless of the housing system and it is consequently recommended to keep males as broil- er quails and slaughter them from 6-7 weeks of age.

\section{Acknowledgements}

The authors express their gratitude to the Centre de Formation Professionnelle et de Promotion de I'Aviculture-Cuniculture Tropicale (CFPPA-CT), southern of Bénin Republic for the provision of facilities for raising the birds and equipment for carcass characteristics determination.

\section{References}

Alamuoye OF and JO Ojo. 2015. Comparison of Carcass characteristics of sexed Japanese Quails (Coturnix coturnix japonica). Sch J Agric Vet Sci. 2(5): 342-344.

Bonos EM, EV Christaki and PC Florou-Paneri. 2010. Performance and carcass characteristics of Japanese quail as affected by sex or mannan oligosaccharides and calcium propionate. South African Journal of Animal Sciences. 40(3): 173184.

Dawkins MS, CA Donnelly and TA Jones. 2004. Chicken welfare is influenced more by housing conditions than by stocking density. Nature. 427(6972): 342-344.

De Verdal H, S Mignon-Grasteau, C Jeulin, E Le Bihan-Duval, M Leconte, $S$ Mallet, $C$ Martin and A Narcy. 2010. Digestive tract measurements and histological adaptation in broiler lines divergently selected for digestive efficiency. Poultry Science. 89(9): 1955-1961.

Favreau-Peigné $A$, L Calandreau, $P$ Constantin, B Gaultier, A Bertin, C Arnould, A Laurence, MA Richard-Yris, C Houdelier, S Lumineau, A Boissy and $C$ Leterrier. 2014. Emotionality modulates the effect of chronic stress on feeding behaviour in birds. PLoS ONE. 9(2). p.e87249.

Fouad MA, AH Abdel Razek and ESM Badawy. 2008. Broilers welfare and economics under two management alternatives on commercial scale. International Journal of Poultry Science. 7(12): 1167-1173.

Kaur S and AB Mandal. 2015. The Performance of Japanese Quail (White Breasted Line) to Dietary 
Energy and Amino Acid Levels on Growth and Immuno-competence. J Nutr Food Sci. 5: 390.

Khaldari M, A Pakdel, H Mehrabani Yegane, A Nejati Javaremi and P Berg. 2010. Response to selection and genetic parameters of body and carcass weights in Japanese quail selected for 4week body weight. Poultry Science. 89(9): 18341841.

Li Y, C Luo, J Wang and F Guo. 2017. Effects of different raising systems on growth performance, carcass, and meat quality of medium-growing chickens. Journal of Applied Animal Research. 45(1): 326-330.

Main DCJ, S Mullan, C Atkinson, M Cooper, JHM Wrathall and HJ Blokhuis. 2014. Best practice framework for animal welfare certification schemes. Trends in Food Science and Technology. 37(2): 127-136.

Marks HL. 1993. Carcass composition, feed intake and feed efficiency following long-term selection for four-week body weight in Japanese quail. Poultry science. 72(6): 1005-1011.

Nasar A, A Rahman, N Hoque, AK Talukder and ZC Das. 2016. A survey of Japanese quail (Coturnix coturnix japonica) farming in selected areas of Bangladesh. Veterinary world. 9(9): 940-947.

Shields S and M Greger. 2013. Animal welfare and food safety aspects of confining broiler chickens to cages. Animals. 3(2): 386-400.

Sogunle OM, LT Egbeyale, TT Bajomo, OV Bamigboje and AO Fanimo. 2008. Comparison of the performance, carcass characteristics and hae- matological parameters of broiler chicks reared in cage and floor. Pakistan Journal of Biological Sciences. 11 (3): 480-483.

Tavaniello S, G Maiorano, M Siwek, S Knaga, A Witkowski, D Di Memmo and M Bednarczyk. 2014. Growth performance, meat quality traits, and genetic mapping of quantitative trait loci in 3 generations of Japanese quail populations (Coturnix japonica). Poultry Science. 93(8): 2129-2140.

Tavaniello S. 2014. Effect of cross-breed of meat and egg line on productive performance and meat quality in Japanese quail (Coturnix japonica) from different generations. Ph. D. Thesis, University of Molise, Italy.

Wei J, RJ Carroll, KK Harden and G Wu. 2012. Comparisons of treatment means when factors do not interact in two-factorial studies. Amino Acids, 42(5): 2031-2035.

Zhao XL, PB Siegel, YP Liu, Y Wang, ER Gilbert, Q Zhu and $L$ Zhang. 2012. Housing system affects broiler characteristics of local Chinese breed reciprocal crosses. Poultry Science. 91(9): 24052410 